\title{
Supratentorial primitive neuroectodermal tumor (PNET) An uncommon location
}

\author{
Fabiano Reis ${ }^{1}$, Guilherme Henrique Alves Vieira ${ }^{4}$, Fabio Rogerio ${ }^{3}$, Marilisa Mantovani Guerreiro5, \\ Luciano de Souza Queiroz ${ }^{2}$, Verônica de Araújo Zanardi ${ }^{1}$
}

A 10-year-old girl with headache. Diagnostic imaging demonstrated a right frontotemporal solid-cystic lesion, in the cortex and white matter, with a component with decrease in diffusion, attributed to high cellularity and nuclear-to-cytoplasmic ratio, which may be seen in PNET or lymphoma ${ }^{1,2}$. A high signal component on T1 and on T2 was observed (extracellular methaemoglobin), often seen in PNET.

Histological analysis led to the diagnosis of PNET .
Supratentorial PNETs are very rare ${ }^{2}$. More than 50\% occur in the first 5 years of life $^{2}$. Our case also merits attention because of the late age at presentation.

\section{REFERENCES}

1. Guo AC, Cummings TJ, Dash RC, Provenzale JM. Lymphomas and highgrade astrocytoma: comparison of water diffusibility and histologic characteristics. Radiology 2002;224:177-183.

2. Klisch J, Husstedt H, Hennings S, Velthoven V, Pagenstecher A, Schumacher M. Supratentorial primitive neuroectodermal tumours: diffusionweighted MRI. Neuroradiology 2000;42:393-398.
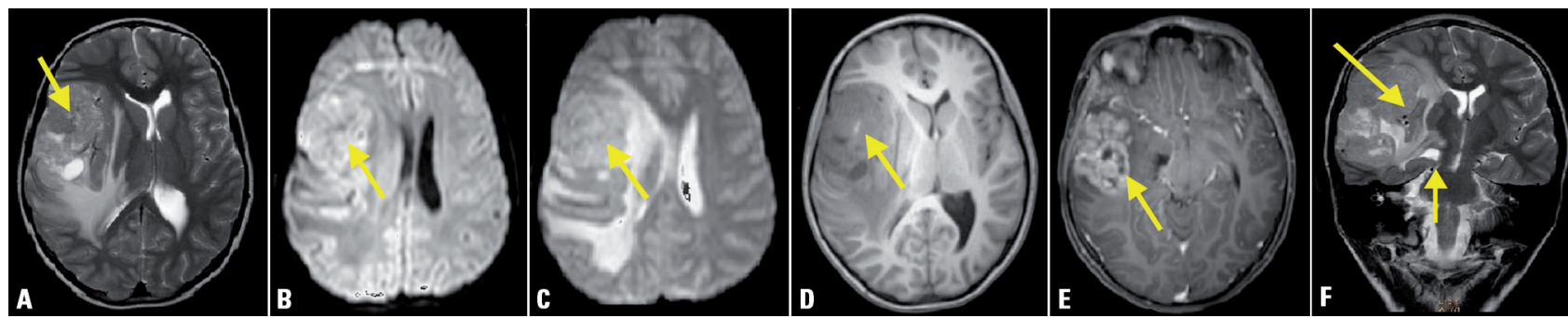

Fig 1. [A] Axial T2 weighted image (WI) demonstrates a large right frontotemporal solid-cystic mass. On DWI [B] and ADC map [C] there is decreased diffusion in the lesion (arrows) (bright on DWI and low intensity in the ADC map). Axial T1 precontrast [D] showed a heterogeneous mass, with a focal high signal (arrow) component (methaemoglobin) and [E] postcontrast T1 shows a heterogeneous enhancing mass. [F] Coronal T2 WI demonstrates heterogeneously low signal (arrow) and there is also right uncal herniation (small arrow)

Fig 2. Neuropathology. A primitive-looking neoplasm with immunohistochemical evidence of differentiation along various neuroectodermal cell lines was consistent with the diagnosis of PNET (primitive neuroectodermal tumor). [A] Surgical specimen measured $8 \times 4 \times 4 \mathrm{~cm}$ and weighed $75 \mathrm{~g}$. Well delimited, lobulated firm mass, with a pale pink cut surface. [B] On HE stain, tissue was composed of small undifferentiated cells in solid lobules, with scattered islets of loosely arranged cells, creating a vague resemblance to desmoplastic medulloblastoma. [C] GFAP- positive cells were interspersed with negative elements. [D] Cytoplasmic staining for nestin, an intermediate filament expressed by immature cells, witnessed the primitive
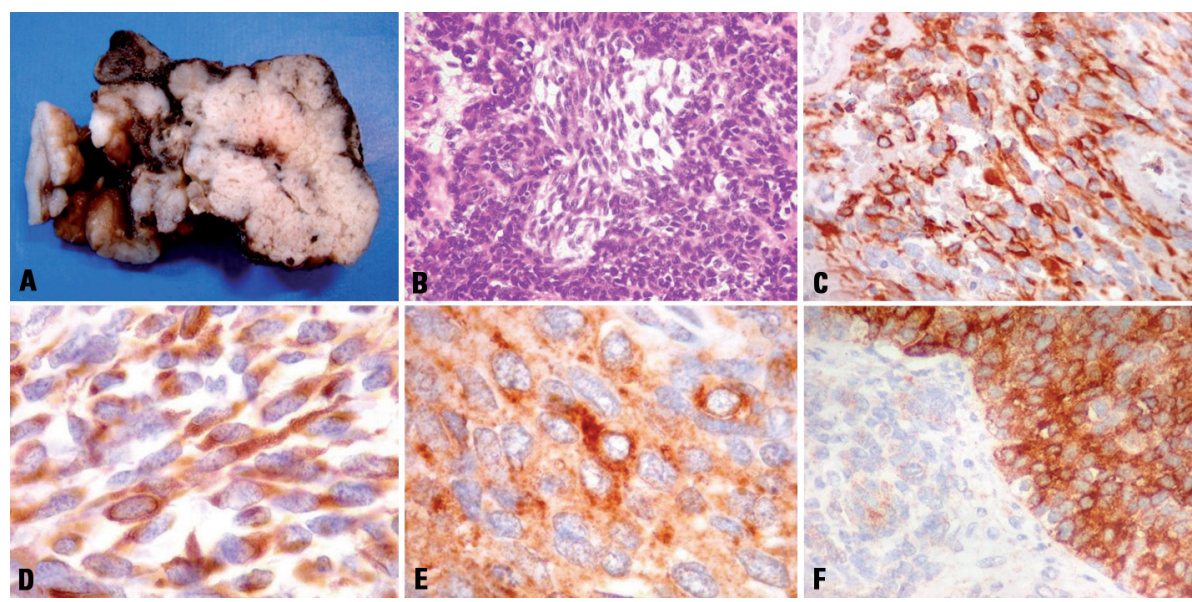

nature of the tumor. [E] Positivity for synaptophysin in the cytoplasm of several cells, some displaying cytoplasmic processes reminiscent of neurites, indicated early neuronal differention. [F] Areas of compactly arranged cells were strongly marked for EMA (epithelial membrane antigen), a common feature of ependymal cells. Adjoining loose cells were negative, creating an organoid pattern.

\section{TUMOR NEUROECTODÉRMICO PRIMITIVO SUPRATENTORIAL: UMA LOCALIZAÇÃO INCOMUM}

${ }^{1} \mathrm{MD}$, PhD, Professor of the Department of Radiology of the Clinics Hospital of the State University of Campinas, Faculty of Medical Sciences (HC-FMC/UNICAMP), Campinas $\mathrm{SP}$, Brazil; ${ }^{2} \mathrm{MD}$, PhD, Professor of the Department of Pathology, HC-FMC/UNICAMP; ${ }^{3} \mathrm{MD}$, PhD, Assistant pathologist Department of Pathology, HC-FMC/UNICAMP; ${ }^{4}$ Medical Student, Department of Radiology, HC-FMC/UNICAMP; ${ }^{5} \mathrm{MD}$, PhD, Full Professor of the Department of Neurology, HC-FMC/UNICAMP;

Correspondence: Fabiano Reis - UNICAMP / Departamento de Radiologia - Rua Tessália Vieira de Camargo 126 - 13083-887 Campinas SP - Brasil. E-mail: fabianoreis2@gmail.com Received 3 June 2011. Accepted 21 June 2011. 